See discussions, stats, and author profiles for this publication at: https://www.researchgate.net/publication/343333228

\title{
Entrepreneurial Characteristics of Principal Partners of Architectural Firms in Lagos, Nigeria
}

Article in Journal of Advanced Research in Dynamical and Control Systems · July 2020

DOI: 10.5373/JARDCS/N12SP7/20202416

CITATIONS

READS

0

37

1 author:

Adedapo Oluwatayo

Covenant University Ota Ogun State, Nigeria

94 PUBLICATIONS 299 CITATIONS

SEE PROFILE

Some of the authors of this publication are also working on these related projects:

Project Characteristics of Architectural firms in Nigeria View project

Project Compliance of academic buildings to universal design principles View project 


\title{
Entrepreneurial characteristics of principal partners of Architectural firms in Lagos, Nigeria
}

\author{
Adedapo A. Oluwatayo a, Adedotun O. Akinola ${ }^{a}$, Oluwatobi Ajayi ${ }^{\text {a }}$, Halima Momoh ${ }^{\text {a }}$, Esther \\ Olashore $^{\mathrm{a}}$, Hilary I. Okagbue ${ }^{\mathrm{b}}$, Nkolika J. Peter ${ }^{\mathrm{c}}$ \\ ${ }^{a}$ Department of Architecture, Covenant University, Ota, Nigeria \\ ${ }^{b}$ Department of Mathematics, Covenant University, Ota, Nigeria \\ ${ }^{c}$ Department of Estate Management, Covenant University, Ota, Nigeria \\ Corresponding Author
}

\begin{abstract}
Very few studies have investigated entrepreneurial characteristics of principal architects, who venture out on their own, rather than practice under established organizations. The research was done to determine and quantify the entrepreneurial characteristics of the principal partners of architectural firms in Lagos, Nigeria. A cross-sectional survey of 92 principal partners of architectural firms in Lagos State, carried out in March 2018 and Questionnaires were used in obtaining the data. Results from the analyzed data showed that there is a correlation between the entrepreneurial characteristics of principal partner and the performance of their firms in that their leadership skill and prowess have a direct influence on their firms. This, however, does not necessarily result in a better outcome in all measures of performance investigated. This is because the two entrepreneurial characteristics only affect the ability of the firms to expand. The recommendation, therefore, is that architecture schools should include leadership training and capacity building programs to produce effective contemporary architects who consequently will lead a successful firm, thus bringing repute to the field of architecture. This research can also be implemented on a large scale in other fields for comparative analysis.
\end{abstract}

Keyword: Architects, barriers, entrepreneur, entrepreneurial characteristics, motivation, Principal architects, Principal partners

\section{Introduction}

Architectural firms are run by principal partners and these partners have a responsibility to themselves and their firms to grow, network and deliver. Principal partners are faced with decisions from day to day, that either build or destroy their firms. They never stop progressing until they attain a certain level of recognition. Being paid for what one is passionate about gives a good feeling, this is a pointer to the fact that love for one's field of study is indeed an entrepreneurial trait for professionals globally.

The ability to lead a group of professionals and allied professionals requires discipline and a high level of commitment to the field. This is why it is important to find out what keeps architectural chief executive officers afloat amid the challenges of leading a firm. Principal partners face multiple responsibilities, which involve decision making, personal and personnel management, professional expectations and family obligations. Despite the responsivities, architectural professionals continue to be leading giants in 
innovative, smart and sustainable building designs (Castro et al., 2018) and high tech interior decorations (Abdrakhmanov, 2018) and development of new building processes, procedures and protocols (Zhou et al., 2017; Sarmiento, 2018).

In the world of architecture today, being a principal partner or starting one's firm is one of the most desired positions by the youngest architects. The gap in the research of principal partners is that none of the previous research in the field has explored the entrepreneurial characteristics of Principal partners of architectural firms and the effect it has on the reputation and profitability of their firm. Previous literature has focused on leadership behaviours of chief executive officers (Wang et al., 2011) and communication skills for workplace success (Doyle, 2017; Peter, Oni, Ogunowo, Fateye, 2019). There is however very little literature that has categorically described the entrepreneurial characteristics that are required for the successful running of an architectural firm and how they influence the firm.

This study aims to investigate the entrepreneurial traits of principal partners in architectural firms in Lagos, to advance the Education and Practice of the Profession. The research is similar to Bahari et al. (2017) but the authors considered different fields and restricted their scope to only women entrepreneurs.

The objectives of this study are to:

a) Examine the socio-economic characteristics of the entrepreneurs of architectural firms in Lagos, Nigeria.

b) Examine the organisational characteristics of their firms.

c) Identify what constitutes entrepreneurial characteristics of principal partners of architectural firms in Lagos, Nigeria.

d) Identify the factors that motivate architect entrepreneurs.

e) Identify factors that are barriers to entrepreneurship in architectural practice

f) Assess the influence of entrepreneurial characteristics of the principal partner on the performance of their firm.

The research will help understand the entrepreneurial traits and their importance to principal partners. Secondly, the findings will present clues on how young architects understand the ways veteran architects have handled limitations as it relates to the profession.

\section{Materials and Methods}

The data analysis in this article was as an outcome of a cross-sectional survey of 92 principal partners of architectural firms in Lagos State, carried out in March 2018, to determine and quantify the entrepreneurial characteristics of the principal partners of architectural firms in Lagos, Nigeria. A questionnaire was designed and purposive sampling was adopted for the survey.

The questionnaire was in four sections. In the first section, the principal partners were asked to rate to what extent some entrepreneurial characteristics applied to them on a scale of 1 to 5, with 1 representing "can never be me" and 5 representing "very much like me". In the second section, they were asked to rate the factors that motivate them on a scale of 1 to 5, with 1 representing "Not a motivation at all" and 5 ISSN: 2005-4238 IJAST 
representing "High motivation". The questions in the third section were on factors that serve as barriers to entrepreneurship. For this, they were asked to rate the factors on a scale of 1 to 5, with 1 representing "No influence" and 5 representing "More Influential". In the fourth section, the respondents rated their performances in terms of profitability, ability to meet obligations, reputation and relationship with stakeholders and the ability to expand the firms on a scale of 1 to 5.1 represented "poor", while 5 represented "very good".

The questionnaires were collected, coded and analysed. The data presented was an outcome of a research question and investigated using questionnaires similar to the ones used in Oluwatayo et al. (2018a; 2018b) and Akinola et al. (2018). Other areas in this aspect have been discussed; such as client satisfaction of building professionals, simulation of variables in the building processes, construction materials, architectural design and project management (Afolabi et al., 2018; Agunloye et al., 2018; Ajakaiye et al., 2018). Factor analysis was employed for the data analysis.

\section{Results}

\subsection{Socioeconomic characteristics of the entrepreneurs of architectural firms in Lagos, Nigeria}

The entrepreneurs were asked to choose the characteristics that best described their person. The survey was used to get the personal data of the principal partners which will be discussed in the course of this analysis.

(a). From the survey, the percentage ratio of men to women is $90.22 \%$ to $9.78 \%$. This shows that we have more males dominating the field of architecture as principal partners than we have females.

(b). We discovered that the architect entrepreneurs within the age group "50 and above" had the highest percentage of " $26.37 \%$ " while the age group of " $25-30$ " had the lowest percentage ratio of " $7.69 \%$ " in our survey. This is understandable since years of experience is required to be a successful entrepreneur in the field.

(c). $49.45 \%$ of the architects have had family members in business before, while $48.35 \%$ of them have not had members of their families in Business.

(d). The highest percentage of the architects are holders of Masters' degrees. This simply means that most architect entrepreneurs have at least their M.Sc. in the bag before branching out to establish their firms.

(e). Most of the architects ventured into business between the ages of 25 and 30. This is expected since work experience is needed before setting up the business. Consequently, 66.3\% of them had had 1-5 years' experience before the establishment of their venture and the least percentage $4.35 \%$ represents the group of architects who had 11-15 years of experience before the establishment of their firms.

(f). The different levels of experience recognized in this analysis are; junior, intermediate and senior. $61.96 \%$ of the architects are on the intermediate level of experience.

(g). Most architects (90.22\%) were exposed to design, being the core of architectural practice in their early days of practice under registered senior colleagues. 


\subsection{Organisational characteristics of their firms.}

The organisational characteristics of the firms are those properties that can be used to describe the firms of the principal partners. The characteristics used by the researchers for this analysis are; the firms' ownership, staff strength of the firm, the number of executed projects by the firm and the firms' specialization.

(a). The ownership of the architectural firms in Lagos, Nigeria is basically, sole principal, partnerships and limited liability companies.

(b). There is an almost even distribution of the firms that have existed for 10-15 years and those have existed for 15 years and above. Each having $30.43 \%$ and $31.52 \%$ respectively.

(c). A third of the architectural firms have between 6 to 10 staff strength.

(d). $60 \%$ of the architectural firms' group has executed between 30 and 70 projects.

(e). Two-third of the firms specialize in design.

\subsection{Entrepreneurial Characteristics of Principal Partner of Architectural Firms}

The entrepreneurs were asked to rate to what extent some characteristics applied to them on a scale of 1 to 5, with 1 representing "can never be me" and 5 representing "very much like me". The data obtained were subjected to factor analysis which yielded 10 factors shown in Table 1. The factors were named based on the general characteristics that apply to the partner.

Table 1: Factors that describe the entrepreneurial characteristic of principal partner of architectural firms

\begin{tabular}{lll}
\hline Factor & Variables & $\begin{array}{l}\text { component } \\
\text { loading }\end{array}$ \\
& & 0.734 \\
\hline $\begin{array}{l}\text { Factor 1: } \\
\text { Charismatic people } \\
\text { personality }\end{array}$ & $\begin{array}{l}\text { endeavouring to impress all my clients apply to you } \\
\text { giving bonuses when due to encourage your employees apply to }\end{array}$ & 0.637 \\
(9.03\%) & you & \\
& having confidence when taking on a project that you will be & 0.626 \\
& successful apply to you & \\
& $\begin{array}{l}\text { following a systematic process when a project is on-going and } \\
\text { ensuring that it is adhered to apply to you }\end{array}$ & 0.611 \\
& always trying to learn lessons from your failures apply to you & 0.594 \\
& building relationships easily apply to you & 0.576 \\
& believing that it is possible to influence ones destiny apply to you & 0.509 \\
\hline $\begin{array}{l}\text { Factor 2: } \\
\text { Authoritarian }\end{array}$ & supervising all projects personally and regularly apply to you & 0.780 \\
(8.83\%) & overseeing all site and organisational meetings apply to you & 0.741 \\
& wanting to be the sole decision maker and having liberty to take & 0.691
\end{tabular}




\begin{tabular}{|c|c|c|}
\hline & $\begin{array}{l}\text { How relating to all your clients and listening to all their wants and } \\
\text { needs even when it cannot be apply to you }\end{array}$ & 0.607 \\
\hline & $\begin{array}{l}\text { not seeing any design proposal as impossible but tasking and brain } \\
\text { storming apply to you }\end{array}$ & -0.582 \\
\hline \multirow{4}{*}{$\begin{array}{l}\text { Factor 3: } \\
\text { Self-motivation } \\
(6.68 \%)\end{array}$} & being goal oriented apply to you & 0.726 \\
\hline & $\begin{array}{l}\text { having no problem with approaching a prospective client apply to } \\
\text { you }\end{array}$ & 0.627 \\
\hline & $\begin{array}{l}\text { believing that everything is possible as far as you believe you can } \\
\text { do it apply to you }\end{array}$ & 0.591 \\
\hline & liking departments that are well-structured apply to you & 0.586 \\
\hline \multirow{3}{*}{$\begin{array}{l}\text { Factor 4: } \\
\text { Melancholy } \\
(6.40 \%)\end{array}$} & being a lot less effective in stressful situations apply to you & -0.834 \\
\hline & taking a very long time to come up with designs apply to you & -0.729 \\
\hline & $\begin{array}{l}\text { keeping the clients up to date on the progress of a project by } \\
\text { sending various reports apply to you }\end{array}$ & 0.635 \\
\hline \multirow{5}{*}{$\begin{array}{l}\text { Factor 5: } \\
\text { Good Leader } \\
(5.88 \%)\end{array}$} & adapting a specific design philosophy in the firm apply to you & 0.714 \\
\hline & trying to be as approachable as possible apply to you & 0.622 \\
\hline & always being in the midst of launching new projects apply to you & 0.596 \\
\hline & being open to criticism both positive and negative apply to you & 0.535 \\
\hline & maintaining an open door policy in the firm apply to you & 0.532 \\
\hline \multirow{3}{*}{$\begin{array}{l}\text { Factor 6: } \\
\text { Firmness } \\
(5.72 \%)\end{array}$} & $\begin{array}{l}\text { endeavouring to make the work place a lively and enjoyable place } \\
\text { apply to you }\end{array}$ & 0.708 \\
\hline & $\begin{array}{l}\text { ensuring that all workers resume on time and that all office } \\
\text { regulations are adhered to apply to you }\end{array}$ & 0.693 \\
\hline & being fairly at ease in difficult situations apply to you & 0.667 \\
\hline \multirow{3}{*}{$\begin{array}{l}\text { Factor } 7: \\
\text { Thorough } \\
(5.23 \%)\end{array}$} & $\begin{array}{l}\text { ensuring all projects are completed to a standard and acceptable } \\
\text { level apply to you }\end{array}$ & 0.786 \\
\hline & preferring to be your own boss apply to you & 0.593 \\
\hline & $\begin{array}{l}\text { being actively involved in building designs with or without a brief } \\
\text { apply to you }\end{array}$ & 0.505 \\
\hline \multirow[t]{2}{*}{$\begin{array}{l}\text { Factor 8: Prowess } \\
(4.98 \%)\end{array}$} & $\begin{array}{l}\text { having received a reasonable amount of recommendations based } \\
\text { on past projects apply to you }\end{array}$ & 0.806 \\
\hline & $\begin{array}{l}\text { having an in-depth understanding of the job requirement of the } \\
\text { masons apply to you }\end{array}$ & 0.799 \\
\hline
\end{tabular}




\begin{tabular}{lll}
\hline $\begin{array}{l}\text { Factor 9: } \\
\text { Team Player }\end{array}$ & $\begin{array}{l}\text { coordinating clients and employee participation in all projects } \\
\text { apply to you }\end{array}$ & -0.552 \\
$(4.48 \%)$ & $\begin{array}{l}\text { accepting ideas from all professionals in the firm apply to you } \\
\text { Factor 10: }\end{array}$ & -0.527 \\
$\begin{array}{l}\text { Life-long learning } \\
(4.28 \%)\end{array}$ & $\begin{array}{l}\text { apply to you } \\
\text { being actively involved in every aspect of the creative process }\end{array}$ & 0.748 \\
& \begin{tabular}{l} 
apply to you \\
\hline
\end{tabular}
\end{tabular}

Charismatic, authoritarian and self-motivation are the three leading factors that describe the entrepreneurial characteristic of principal partner of architectural firms in Lagos, Nigeria.

\subsection{Motivating Factors of Architect Entrepreneurs}

The entrepreneurs were asked to rate the factors that motivate them on a scale of 1 to 5 , with 1 representing "Not a motivation at all" and 5 representing "High motivation". The data were subjected to mean ranking. The researchers carried out the survey to examine which factors were the highest and which were the lowest in motivating the architect entrepreneurs to start their venture. Assumptions were already formed by the researchers on what factors were more important than others. The results have been reviewed below using Table 2.

The descriptive statistics (Table 2) below shows that the desire to earn personal money was the highest motivating factor. It has been shown in different situations that people measure success based on the amount of money they earn on their own or wealth they can gather through their means. This being a motivating factor simply shows that most architect entrepreneurs need to be successful and earn their own money (Tran, 2019). This ranking as the highest proved one of the researchers' assumptions as being correct because it is human nature to have a personal identity and success not affiliated with that of others. The ability to use their skills to create opportunities continues to be one of the key motivating factors of the entrepreneurs, which was re-echoed in this work (Yusof et al., 2017).

Table 2: Mean ranking of the motivating factors of principal partners of architectural firms

\begin{tabular}{lllc}
\hline Descriptive Statistics & & & \\
\hline & $\mathrm{N}$ & Mean & Std. Deviation \\
\hline desire to earn your own money & 92 & 4.55 & 0.652 \\
need to use technical or professional & 92 & 4.42 & 0.745 \\
knowledge and skills & & & \\
more exposure & 92 & 4.25 & 1.125 \\
previous experience or association & 92 & 4.17 & 0.833 \\
with same or similar & & & \\
line of business activity & & & \\
the market & 92 & 4.16 & 1.286 \\
need to utilize better opportunity & 91 & 4.15 & 1.273 \\
\hline
\end{tabular}




\begin{tabular}{lccc}
\hline $\begin{array}{l}\text { need to secure self-employment or } \\
\text { independence }\end{array}$ & 92 & 4.09 & 1.145 \\
$\quad$ more career advancement & 92 & 4.01 & 1.288 \\
need to implement own Business idea & 92 & 3.91 & 1.340 \\
$\quad$ influence and encouragement by family & 92 & 3.60 & 1.293 \\
members, & & & \\
$\quad$ friends and relatives & & & \\
$\quad$ dissatisfaction with previous job & 92 & 3.48 & 1.305 \\
need to put the owners idle funds in & 92 & 3.29 & 1.347 \\
entrepreneurship & & & \\
government policies and schemes & 92 & 3.25 & 1.502 \\
need to gain social prestige & 92 & 3.24 & 1.261 \\
fear of unemployment & 92 & 2.91 & 1.388 \\
\hline
\end{tabular}

\subsection{Barriers to Entrepreneurship in Architectural Practice}

The entrepreneurs were asked to rate the factors that motivate them on a scale of 1 to 5, with 1 representing "No influence" and 5 representing "More Influential". The data were subjected to mean ranking. The survey was carried out to establish what barriers the architect entrepreneurs encountered. Numerous barriers were listed and the result the researchers obtained showed from the highest and most common barrier to the least barrier the principal partners encountered.

The descriptive statistics (Table 3) show that the availability of capital on the development of entrepreneurial activity ranked the highest barrier in this research. In terms of monetary availability, it is no surprise this is the most faced barrier (Akhter, 2017). Starting a new firm not only takes dedication, passion, drive and time but also a lot of money. In entrepreneurship, capital is the major hindrance to starting up an organisation or firm. This comes as no surprise to the researchers as it is the biggest challenge faced by any entrepreneurs worldwide. In addition, the $b$ Educational barrier and availability of labour are pointers to the dearth of human resources in the area. In addition, those that are not certified as professionals might find it difficult to operate in this terrain as clients prefer to work with those that are duly certified. Entrepreneurs often struggle to meet up with retaining highly skilled workers. Environmental conditions are factors such as regulatory issues, business climate, security, government policies and sustainability (Sa'ari et al., 2017; Moeljadi and Yuniarsa, 2018).

Table 3: Mean ranking of the barriers to entrepreneurship in architecture

\begin{tabular}{lccc}
\hline & $\mathrm{N}$ & Mean & Std. Deviation \\
\hline availability of capital & 92 & 4.42 & 0.716 \\
educational background & 92 & 4.28 & 0.789 \\
availability of labour & 92 & 4.20 & 0.745 \\
practical values & 92 & 4.04 & 0.888 \\
\hline
\end{tabular}




\begin{tabular}{llll}
\hline environmental conditions & 92 & 3.99 & 0.883 \\
social status & 92 & 3.93 & 1.003 \\
government policies/support & 92 & 3.92 & 0.880 \\
society & 92 & 3.88 & 0.900 \\
logic & 92 & 3.86 & 0.921 \\
friends & 92 & 3.82 & 0.926 \\
tradition & 92 & 3.71 & 1.153 \\
fear of failure & 92 & 3.57 & 1.234 \\
corruption & 92 & 3.28 & 1.353 \\
relatives & 92 & 3.24 & 1.103 \\
family background & 92 & 3.20 & 1.160 \\
personal bad experience & 92 & 3.17 & 1.154 \\
religion & 92 & 3.12 & 1.088 \\
bad experience of others & 92 & 2.77 & 1.360 \\
\hline
\end{tabular}

6.0 Influence of Entrepreneurial Characteristics of The Principal Partner on The Performance of Their Firms

The influence of entrepreneurial characteristics of the principal partner on the performance of Architectural firms was explained in the level of firm's profitability, the ability of the firms to commit to their required obligations, firms' reputation and the drive for expansion.

\subsection{Level of Firms Profitability}

This analysis seeks to analyse the principal partner's perception of the profitability of their firms. It comes as no surprise that $55.43 \%$ of architectural firms are making good profit.it is however a concern that $7.61 \%$ of architectural firms are not making good profit, this will affect their ability to meet their organisational obligations and their expansion capacity.

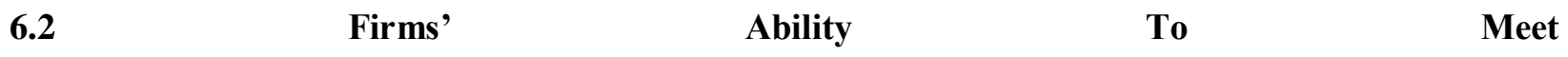

\section{Obligations}

The hallmark of a firm with a stable business structure is based on their ability to pay staff, maintain office obligations and as many requirements that enhance the smooth day-to-day running of the firm. According to this research, $51.09 \%$ of the firms are effectively meeting their organisational obligations. 


\subsection{Reputation and Relationship of Firm and Stakeholders}

The result from the survey revealed that $57.61 \%$ of the firms believe that they have a very good reputation and relationship with other stakeholders, this is no surprise because communication and reputation play a very big role in success in the field of architecture. Many firms get their contracts via recommendation which comes after successful completion of projects or contracts.

\subsection{Ability of The Firm to Expand}

This analysis is a clear indication that Nigerian architectural firms are making a profit, about $44.57 \%$ have the ability to expand and increase the workforce but they would usually prefer to remain the way they are, this is for the maximization of profit made and to reduce remunerations.

\subsection{Regression analysis}

Regression analysis was carried out to determine the entrepreneurial characteristics that influenced firm performance. The performance of the firms and the factored characteristics of the entrepreneurs (10) were analysed preliminarily to ensure linearity was not violated. The results were summarized in Table $\mathbf{4}$ and it was revealed that only the ability to expand was significantly influenced by the entrepreneurial characteristics of principal partners of architectural firms. A significant regression equation was found ( $F$ $(10,73)=4.346, p<0.000$, with an $\mathrm{R}$ square of 0.373 . The performance indices used were profitability, ability to meet obligations, ability to expand, reputation and relationship with stakeholders. The model summary (Table 4) shows that the significant entrepreneurial characteristics account for $37.3 \%$ of the variance in the firms' ability to expand. The coefficients show Good Leadership skill (0.000) and Prowess (0.026) are the significant entrepreneurial characteristics that affect the ability of the firm to expand. The results did not correlate with the assumptions of the researchers as it was expected that firms' performance such as; profitability and ability to meet obligations will be affected by the factored characteristics. As discussed earlier, the ability to expand shows a high level of profitability enough for firms' expansion, therefore, the factored characteristics may not directly influence firms' profitability but to a certain level of expansion, it does.

Table 4: Summary of the Regression analysis of the factors that predict firms' ability to expand

\begin{tabular}{|c|c|c|c|c|c|c|}
\hline \multicolumn{2}{|c|}{ Model } & \multicolumn{2}{|c|}{$\begin{array}{l}\text { Unstandardized } \\
\text { Coefficients }\end{array}$} & $\begin{array}{l}\text { Standardized } \\
\text { Coefficients } \\
\text { Beta }\end{array}$ & $\mathrm{T}$ & Sig. \\
\hline \multirow[t]{7}{*}{1} & (Constant) & 4.202 & 0.081 & & 52.134 & 0.000 \\
\hline & Charismatic personality & 0.148 & 0.081 & 0.169 & 1.827 & 0.072 \\
\hline & Authoritarian & -0.137 & 0.081 & -0.157 & -1.692 & 0.095 \\
\hline & Self-motivation & -0.036 & 0.081 & -0.041 & -0.446 & 0.657 \\
\hline & Melancholy & 0.071 & 0.081 & 0.081 & 0.870 & 0.387 \\
\hline & Good Leader & 0.429 & 0.081 & 0.490 & 5.290 & 0.000 \\
\hline & Firmness & -0.041 & 0.081 & -0.047 & -0.504 & 0.616 \\
\hline
\end{tabular}

ISSN: 2005-4238 IJAST

Copyright (C) 2020 SERSC 


\begin{tabular}{lccccc}
\hline Thorough & 0.097 & 0.081 & 0.111 & 1.197 & 0.235 \\
Prowess & 0.185 & 0.081 & 0.211 & 2.275 & 0.026 \\
Team Player & -0.087 & 0.081 & -0.100 & -1.079 & 0.284 \\
Life-long learning & -0.043 & 0.081 & -0.049 & -0.532 & 0.596 \\
R square & 0.0373 & & & \\
F & 4.346 & & & \\
$p$ & 0.000 & & &
\end{tabular}

\section{CONCLUSION}

This study has helped to identify the entrepreneurial characteristics of principal partners of architectural firms in Lagos, Nigeria and its influence on the performance of their firms, although those characteristics are not the only factors that completely predict success (Omar et al., 2017). The findings from this study will help young architects and aspiring principal partners identify the most effective entrepreneurial characteristics to cultivate for success in running their firms. The success of their firms is highly needed in sustaining economic growth and creating much-needed employment opportunities (Set, 2017). Excellent leadership skills and dexterity are the key variables that can predict the ability of architectural firms to expand which has the possibility to create jobs in the built environment. Educational institutions should include leadership courses in their curriculum to adequately prepare the students for future leadership roles. Urgent intervention from Government is needed to ensure that architectural schools and departments are fully equipped to adequately train the students, thereby impacting on their competencies and skill levels.

\section{Acknowledgement}

Covenant University is acknowledged for the sponsorship.

\section{References}

1. Abdrakhmanov KA (2018). Merchants' hotel businesses as a part of urban everyday life in the towns of the Orenburg governorate during the post-reform period. Bylye Gody, 50(4), 1644-1655.

2. Afolabi AO, Ojelabi RA, Adewale B, Akinola AO and Afolabi A (2018). Statistical exploration of dataset examining key indicators influencing housing and urban infrastructure investments in megacities. Data in Brief, 18: 1725-1733.

3. Agunloye OO, Ajakaiye OO, Akinola AO, Okagbue HI and Afolabi A (2018). Datasets on factors influencing the urban environmental quality of intra-urban motor parks across density areas of Lagos metropolis. Data in Brief, 19: 2109-2118.

4. Ajakaiye OO, Afolabi HA, Akinola AO, Okagbue HI, Olagunju OO and Adetoro OO (2018). Datasets on factors influencing trading on pedestrian bridges along Ikorodu road, Lagos, Nigeria. Data in Brief, 19: 1584-1593.

5. Akhter F (2017). Strategic imperatives and core competencies to empower small and medium enterprises. International Journal of Advanced and Applied Sciences, 4(4): 170-174. 
6. Akinola AO, Adeboye AB, Oluwatayo A, Alagbe O, Babalola O and Afolabi AO (2018). Survey dataset on architect's awareness and adoption of building envelope technologies for energy efficient housing in Lagos State. Data in Brief, 19: 1894-1901.

7. Bahari N, Jabar J and Yunus, AR (2017). Malaysian women entrepreneurial characteristics, strategic orientation and firm performance: The moderator role of government support programs. International Journal of Advanced and Applied Sciences, 4(12): 257-262.

8. Castro JA, Sánchez-Friera P, Aguilar H and Vargas AL (2018). Design of a smart structured skin to capture solar energy: An experience of international interdisciplinary cooperation. Interciencia, 43(11): 792-798.

9. Doyle A. (2017). Communication Skills for Workplace Success. Retrieved December 11, 2017, from the balance website: https://www.thebalance.com/communication-skills-list-2063779.

10. Moeljadi PS and Yuniarsa SO (2018). Exploring of coastal communities and economic empowerment to the environment impact in maritime. International Journal of Management and Business Research, 8(2), 223-231.

11. Oluwatayo A, Akinola AO, Agomuo IU, Mozimo SO, Onwuka CC and Okagbue HI (2018b). Survey dataset on factors that influence satisfaction of clients with architectural services in Lagos State, Nigeria. Data in Brief, 20: 118-125.

12. Oluwatayo A, Akinola AO, Babalola T, Okagbue HI, Olademehin S, Eyiaro S, Oludara S, Johnson O, Famurewa O, Obi O, Adewakun A and Ekara EN (2018a). Survey data on user's perception of flexibility of spaces in selected cultural center in southwest Nigeria. Data in Brief, 19: 1888-1893.

13. Omar K, Anuar MM, Ahmad A, Zulkifli SNA and Hau, TC (2017). Personality and business performance: A case of entrepreneurs. International Journal of Advanced and Applied Sciences, 4(12): 231-237.

14. Peter, N. J., Oni, A.S., Ogunowo, O.E. and Fateye, O. B. (2019). An Assessment of Workers' Satisfaction in Estate Surveying and Valuation Firms in Lagos State, Nigeria. International Journal of Management (IJM) Volume 10, Issue 02, 2020, pp.86-99.

15. Sa'ari JR, Jabar J, Tahir MNH and Mahpoth, MH (2017). Farmer's acceptance towards sustainable farming technology. International Journal of Advanced and Applied Sciences, 4(12): 220-225

16. Sarmiento E (2018). The affirming effects of entrepreneurial redevelopment: Architecture, sport, and local food in Oklahoma City. Environment and Planning A, 50(2), 327-349.

17. Set K (2017). The awareness and use on government assistance programs among tourism entrepreneurs in Malaysia. International Journal of Advanced and Applied Sciences, 4(12): 226230.

18. Tran TT (2019). An investigation about the satisfaction and loyalty of workers in Taiwanese enterprises located in Vietnam. International Journal of Advanced and Applied Sciences, 6(3): 111.

19. Wang S, Tsui and Xin R (2011). CEO leadership behaviours, organisational performance, and employees' attitudes. The Leadership Quarterly, 22(1): 92-105.

20. Yusof SWM, Jabar J, Murad MA and Ortega, RT (2017). Exploring the cultural determinants of entrepreneurial success: The case of Malaysia. International Journal of Advanced and Applied Sciences, 4(12): 287-297.

21. Zhou, J., Jiao, H. \& Li, J. (2017). Providing appropriate technology for emerging markets: Case study on China's solar thermal industry. Sustainability, 9(2), Article number 178. 